\title{
A new and early marker in the diagnosis of acute complicated appendicitis: immature granulocytes
}

\author{
(1) Yılmaz Ünal, M.D.
}

Department of General Surgery, Ankara Training and Research Hospital, Ankara-Turkey

\begin{abstract}
BACKGROUND: The aim of this study was to investigate the effectiveness of the immature granulocyte (IG) count (IGC) and percentage (IG\%) in both diagnosing acute appendicitis (AA) and discriminating between simple appendicitis (SA) and complicated appendicitis (CA).

METHODS: This study was carried out using the data of 438 adult patients who underwent an appendectomy. Demographic details, the preoperative white blood cell (WBC) count, neutrophil/lymphocyte ratio (NLR), IGC and IG\%, operation findings, and pathology results were assessed retrospectively. The patients were grouped as AA and normal appendix (NA) according to the pathology reports, and the AA cases were subdivided into SA and CA groups according to the intraoperative findings.

RESULTS: WBC, NLR, IGC, and IG\% were significant parameters in the diagnosis of AA. The area under the receiver operating characteristic curve (AUROC: 0.795$)$, sensitivity (55.5\%) and specificity (96.1\%) values of IGC were higher than the other parameters. All of the parameters were also significant for a CA diagnosis; however, the value of IG\% in a CA diagnosis was stronger than the other parameters (IG\% AUROC: 0.979 , sensitivity: $94.4 \%$, specificity: $97.9 \%$ ).
\end{abstract}

CONCLUSION: The IG value is a fast, easily available, and reliable parameter in both diagnosing AA and discriminating between SA and CA.

Keywords: Appendicitis; diagnosis; immature granulocytes.

\section{INTRODUCTION}

Acute appendicitis (AA) is the most frequent cause of acute abdominal pain and typically requires emergency surgical intervention; an appendectomy is the most frequently performed emergency operation. ${ }^{[1]}$ Almost $8 \%$ of the general population in Western countries will undergo an appendectomy during their lifetime. ${ }^{[2]}$ Most AA cases are simple appendicitis (SA) without complications. The perforation rate is typically between $20 \%$ and $30 \%$; however, this rate can be as high as $\mathbf{5 0 \%}$ in elderly patients. ${ }^{[3,4]}$ Acute complicated appendicitis (CA) is a serious problem that increases the risk of postoperative complications, delays recovery, and increases the length of hospital stay and medical costs. ${ }^{[5]}$ Therefore, early diagnosis and treatment of CA is critically important. ${ }^{[6]}$
Numerous studies have been carried out to improve the early diagnosis and treatment of acute complicated appendicitis (ACA). Researchers have used various biomarkers for this purpose, including the white blood cell (WBC) count, erythrocyte sedimentation rate (ESR), C-reactive protein (CRP) and bilirubin levels, and the neutrophil/lymphocyte ratio (NLR). ${ }^{[7-13]}$ However, despite the use of all of these biomarkers as well as radiological methods, it is still difficult to clearly differentiate between SA and CA. There is need for a more specific biomarker for this discrimination.

Immature granulocytes (IG) in the peripheral blood is an indicator of increased bone marrow activation. ${ }^{[14]}$ Due to technical developments in automated hematological analyzers, the quantity of IG can easily be measured when performing a

Cite this article as: Ünal Y. A new and early marker in the diagnosis of acute complicated appendicitis: immature granulocytes. Ulus Travma Acil Cerrahi Derg 2018;24:434-439.

Address for correspondence: Yılmaz Ünal, M.D.

Ankara Eğitim ve Araştırma Hastanesi, Genel Cerrahi Kliniği, Ankara, Turkey

Tel: +90 312 - 5953000 E-mail: yilmazunal66@mynet.com

Ulus Travma Acil Cerrahi Derg 2018;24(5):434-439 DOI: 10.5505/tjtes.2018.9166I Submitted: 26.04.2018 Accepted: 04.09.2018 Online: 20.09.2018

Copyright 2018 Turkish Association of Trauma and Emergency Surgery 
routine complete blood count $(\mathrm{CBC})$ and be presented as a new inflammation biomarker. ${ }^{[14-16]}$ Studies have shown that IG count (IGC) and percentage (IG\%) are significantly increased in sepsis and infections when compared with healthy individuals. $^{[16-18]}$ This study was an investigation of the effectiveness of IG, a new marker of inflammation, in both diagnosing $A A$ and discriminating between SA and CA.

\section{MATERIALS AND METHODS}

This study was carried out retrospectively from April 2017 to February 2018 on 438 adult patients (>18 years) who underwent an appendectomy with a prediagnosis of $A A$ at the General Surgery Clinic of the Ankara Training and Research Hospital. Patients under the age of 18 years, pregnant women, and those with additional diseases that could affect inflammation markers were excluded from the study. Moreover, people who were hospitalized with a prediagnosis of AA and discharged from hospital after receiving medical treatment were not included in the study. The demographic data, laboratory values, operation findings, and pathology results of the 438 patients included in the study were analyzed using the records of the hospital database.

For patients who presented at the emergency department with acute abdominal pain, after obtaining the clinical history and providing physical treatment, a CBC was performed if there was a suspicion of AA. WBC count, neutrophil count, lymphocyte count, and IG\% were measured using an automated hematological analyzer (XN 3000; Sysmex Corp., Kobe, Japan) from blood samples obtained preoperatively at the initial admission to the emergency department. The NLR and IGC were calculated using the data obtained from the $\mathrm{CBC}$ analysis.

The cases were divided into 2 groups: AA and normal appen$\operatorname{dix}(\mathrm{NA}$; negative appendectomy) according to the pathology reports. The AA group was subdivided into cases of simple acute appendicitis (ASA) (catarrhal and phlegmonous) and complicated acute appendicitis (ACA) (gangrenous, perforated, and abscess). The demographic data and preoperative laboratory findings were analyzed statistically and compared.

\section{Statistical Analysis}

The data were assessed using the IBM SPSS Statistics for Windows, Version 22.0 software package (IBM Corp., Armonk, NY, USA). The number of units ( $n$ ) and percentage (\%), mean $( \pm)$, SD ( $x \pm s s)$, and median (interquartile range [IQR]) values were provided as descriptive statistics. The Pearson chisquare and Fischer's exact tests were used to assess categorical variables. Numerical variables with a normal distribution were assessed with the Shapiro-Wilk test, normality test, and $\mathrm{Q}-\mathrm{Q}$ graphics. When comparing 2 groups, the independent sample t-test was used for variables demonstrating normal distribution, while the Mann-Whitney $U$ analysis was used for variables that did not have a normal distribution. Receiving operating characteristic (ROC) curve analysis was performed in order to determine the success of laboratory parameters in predicting cases of AA and CA. The threshold values were identified using the Youden index. The specificity values were calculated based on the obtained threshold values. The value of $p<0.05$ was accepted as statistically significant.

\section{RESULTS}

The present study included 438 patients who underwent an appendectomy with a prediagnosis of AA. Of the group, 234 of the patients $(53.4 \%)$ were male, while 204 were female $(46.6 \%)$. The median age was 30 years $(17,25)$. The youngest patient was aged 18 years, and the oldest 92 .

According to the pathology results, 412 of the patients (94.07\%) were found to have AA and 26 (5.93\%) had NA. The rate of NA was higher among women than men $(8.3 \%$ and $3.8 \%$, respectively), which was a statistically significant difference $(p=0.047)$. In the AA group, the mean values of WBC, NLR, IGC, and IG\% were significantly higher than in the NA group ( $p<0.00$ I for all of the parameters). The comparison between the NA and AA groups is presented in Table I.

The 4I2 patients diagnosed with AA pathologically were grouped as ASA and ACA. Of these 412 patients, 340 (82.9\%) were in the ASA group, while 72 (17.9\%) were ACA cases. No significant difference was found between the ASA and ACA groups in terms of gender $(p=0.223)$. The mean age of the patients was determined to be higher in the ACA group than in the ASA group $(p<0.00 I)$.

The mean WBC, NLR, IGC, and IG\% in the ACA group was found to be significantly higher than in the SAA group ( $p<0.00$ I for all of the parameters). The comparison between the ASA and ACA groups is provided in Table 2.

Table I. The comparison of demographic data and laboratory findings between acute appendicitis and normal appendix

\begin{tabular}{lccc}
\hline & $\begin{array}{c}\text { Acute } \\
\text { appendicitis }\end{array}$ & $\begin{array}{c}\text { Normal } \\
\text { appendix }\end{array}$ & p \\
\hline Number of patients & $412(94.7 \%)$ & $26(5.9 \%)$ & \\
Female & $187(91.7 \%)$ & $17(8.3 \%)$ & 0.047 \\
Male & $225(94.07 \%)$ & $9(3.8 \%)$ & 0.047 \\
WBC $(\mu \mathrm{L})$ & $14700(5900)$ & $10550(68500)$ & $<0.001$ \\
NLR & $5.4(5)$ & $3.08(2.9)$ & $<0.00$ I \\
IGC $(\mu \mathrm{L})$ & $65.6(49.2)$ & $38.3(31.7)$ & $<0.001$ \\
IG\% & $0.4(0.2)$ & $0.3(0.1)$ & $<0.00$ I \\
\hline
\end{tabular}

IG\%: Immature granulocyte percentage; IGC: Immature granulocyte count; NLR: Neutrophil-to-lymphocyte ratio; WBC: White blood cell. 
Table 2. The comparison of demographic data and laboratory findings between simple and complicated appendicitis groups

\begin{tabular}{lccc}
\hline & $\begin{array}{c}\text { Simple } \\
\text { appendicitis }\end{array}$ & $\begin{array}{c}\text { Complicated } \\
\text { appendicitis }\end{array}$ & p \\
\hline Number of patients & $340(82.5 \%)$ & $72(17.5 \%)$ & \\
Female & $159(85 \%)$ & $28(15 \%)$ & $=0.223$ \\
Male & $181(80.4 \%)$ & $44(19.6 \%)$ & $=0.223$ \\
Age $($ years $)$ & $29.5(16)$ & $36.5(25.75)$ & $<0.00$ I \\
WBC $(\mu L)$ & $14050(54500)$ & $18350(55300)$ & $<0.00$ I \\
NLR & $4.9(4.4)$ & $8.8(6.9)$ & $<0.00$ I \\
IGC $(\mu L)$ & $56.4(38.7)$ & $146.4(59.1)$ & $<0.00$ I \\
IG\% & $0.4(0.2)$ & $0.8(0.1)$ & $<0.00$ I \\
\hline
\end{tabular}

IG\%: Immature granulocyte percentage; IGC: Immature granulocyte count; NLR: Neutrophil-to-lymphocyte ratio; WBC: White blood cell.

ROC curves were drawn in order to calculate the effectiveness of laboratory parameters (WBC, NLR, IGC, IG\%) to diagnose AA and to discriminate between ASA and ACA (Fig. I and 2). The prediction ability of all of the parameters to diagnose $A A$ and differentiate between ASA and ACA was significant $(p<0.00 \mathrm{I}$ for all of the parameters). However, the ability of IGC to predict AA was greater than that of the other parameters (IGC area under the ROC [AUROC]: 0.795 , sensitivity: $55.9 \%$, specificity: $96.1 \%)$. The results of the ROC analysis can be seen in Table 3.

While the prediction ability of the IG\% in AA diagnosis was similar to that of the other parameters, its ability to discriminate between ASA and ACA was considerably greater than the others (AUROC: 0.979, sensitivity: $94.4 \%$, specificity: 97.9\%) (Table 4). When the IG\% and the IGC were compared

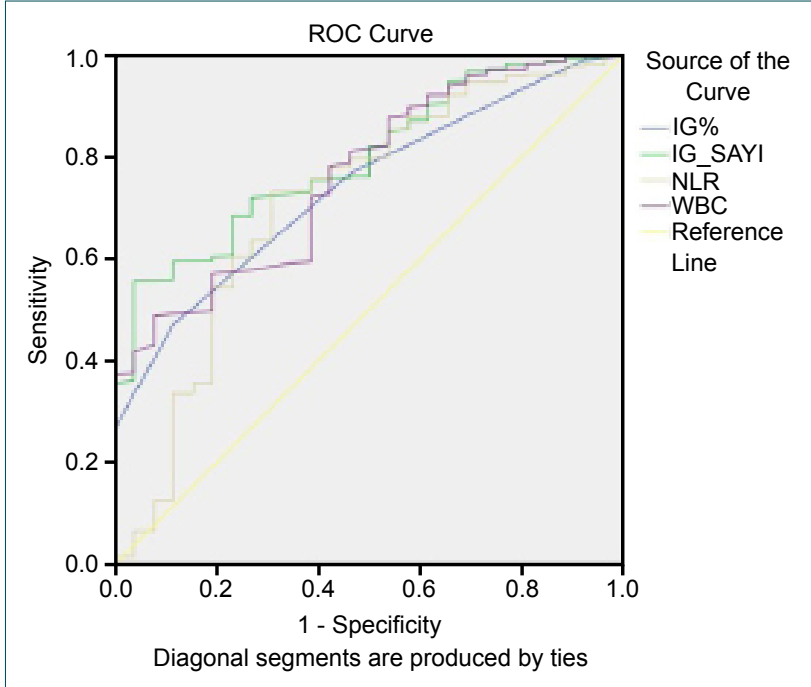

Figure 1. Receiver operating characteristic curve analysis of laboratory parameters in the discrimination between normal appendix and acute appendicitis. with respect to their ability to discriminate between ACA and ASA, it was observed that the IG\% had a greater ability to discriminate CA from SA but the IGC had a greater ability to discriminate AA from NA.

\section{DISCUSSION}

AA is the most common reason for emergency abdominal surgery all around the world. ${ }^{[I]}$ Laboratory tests, scoring systems and imaging methods are used in AA diagnosis, as well as the clinical history and physical examination. ${ }^{[19]}$ However, it is not always possible to make a final and accurate diagnosis. Despite all of the developments in diagnosis and treatment methods, high NA and perforation rates have still been reported (13-36\%, 12-21\%, respectively). ${ }^{[4,10,12,19-22]}$ Perforation rates can reach $50 \%$, particularly among the elderly. ${ }^{[3,5,6,22]}$ As perforation rates increase, the rates of morbidity and mortality, the duration of hospital stay, and medical costs increase as well. Therefore, new biomarkers are needed in order to reduce the rate of both NA and CA.

The NA rate in this study was $5.97 \%$, which was lower than the rates reported in the literature. This low rate resulted from the application of a non-operative treatment approach. [23] This refers to patients who were hospitalized on suspicion of $\mathrm{AA}$ and showed improvements in clinical and laboratory findings through medical treatment. This patient group was discharged without being operated on and was not included in the study. The NA rate was significantly higher among women than men, which was consistent with the literature. It is thought that this discrepancy might have arisen from difficulties in discriminating AA from emergency gynecological pathologies among young women.

The CA rate was $17.5 \%$ in the present study and it was observed at older ages compared with the incidence of SA. Th-

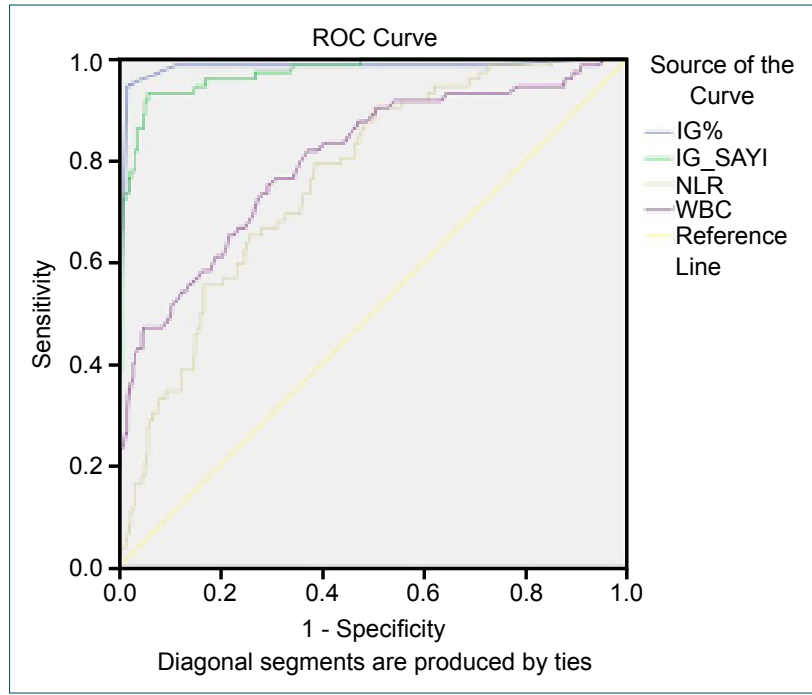

Figure 2. Receiver operating characteristic curve analysis of laboratory parameters in the discrimination between simple appendicitis and complicated appendicitis. 
Table 3. The ROC analysis of parameters in the prediction of acute appendicitis

\begin{tabular}{|c|c|c|c|c|c|c|c|}
\hline & \multirow[t]{2}{*}{ AUROC } & \multicolumn{2}{|c|}{$\mathbf{9 5} \%$ confidence interval } & \multirow[t]{2}{*}{ Cut-off } & \multirow[t]{2}{*}{ Sensitivity (\%) } & \multirow[t]{2}{*}{ Specificity (\%) } & \multirow[t]{2}{*}{$\mathbf{p}$} \\
\hline & & Lower limit & Upper limit & & & & \\
\hline White blood cell & 0.763 & 0.679 & 0.847 & $>14800 /(\mu \mathrm{L})$ & 48.7 & 92.3 & 0.001 \\
\hline Neutrophil-to-lymphocyte ratio & 0.713 & 0.599 & 0.828 & $>3.5$ & 73.3 & 69.2 & 0.001 \\
\hline Immature granulocyte count & 0.795 & 0.724 & 0.867 & $>60.5 /(\mu \mathrm{L})$ & 55.5 & 96.1 & 0.001 \\
\hline Immature granulocyte percentage & 0.739 & 0.658 & 0.821 & $>0.4$ & 47 & 88.4 & 0.001 \\
\hline
\end{tabular}

AUROC: Area under the ROC curve; ROC: Receiver operating characteristic.

Table 4. ROC analysis of parameters in predicting complicated appendicitis

\begin{tabular}{|c|c|c|c|c|c|c|c|}
\hline & \multirow[t]{2}{*}{ AUROC } & \multicolumn{2}{|c|}{$\mathbf{9 5} \%$ confidence interval } & \multirow[t]{2}{*}{ Cut-off } & \multirow[t]{2}{*}{ Sensitivity (\%) } & \multirow[t]{2}{*}{ Specificity (\%) } & \multirow[t]{2}{*}{$\mathbf{p}$} \\
\hline & & Lower limit & Upper limit & & & & \\
\hline White blood cell & 0.798 & 0.737 & 0.859 & $>15800 /(\mu \mathrm{L})$ & 75 & 70.2 & 0.001 \\
\hline Neutrophil-to-lymphocyte ratio & 0.760 & 0.705 & 0.816 & $>5.6$ & 79.1 & 61.1 & 0.001 \\
\hline Immature granulocyte count & 0.968 & 0.948 & 0.988 & $>104.4 /(\mu \mathrm{L})$ & 93 & 93.8 & 0.001 \\
\hline Immature granulocyte percentage & 0.979 & 0.955 & 1.000 & $>0.6$ & 94.4 & 97.9 & 0.001 \\
\hline
\end{tabular}

AUROC: Area under the ROC curve; ROC: Receiver operating characteristic.

ese results were also consistent with the literature..$^{[5,6,22]}$ This might be because elderly people often present to hospital late because their AA symptoms are obscure.

In AA diagnosis, a high WBC count is significant, but not diagnostic. The physiological response of leukocytes in circulation to stress leads to an increase in neutrophil numbers and a decrease in lymphocyte numbers. Thus, the ratio of these 2 subgroups (NLR) is used as a parameter of inflammation. ${ }^{[7-13]}$

In a study designed by Kahramanca et al. ${ }^{[9]}$ it was determined that NLR was a useful parameter for diagnosing AA and discriminating between SA and CA. In a study involving 3392 cases, Sevinç et al. ${ }^{[12]}$ found that the WBC count was not a significant parameter in CA diagnosis, though it was significant in diagnosing AA. Moreover, they stated that a serum bilirubin level greater than $1.0 \mathrm{mg} / \mathrm{dL}$ and an NLR greater than 4.8 contributed to perforation in patients with acute abdominal pain. Bröker et al. ${ }^{[10]}$ and Moon et al. ${ }^{[24]}$ found that the possibility of CA increased in cases in which the CRP level was high, suggesting that proper treatment be carried out immediately in these cases. In the present study, an NLR $>3.5$ supported an AA diagnosis and an NLR >5.6 supported a diagnosis of $\mathrm{CA}$.

An increase of IG in circulation is a reaction of the blood marrow against bacterial infection. In recent years, it has been possible to detect the percentage and number of IG due to technical developments in automated hematological analyzers. [14-16] Recent studies have demonstrated that IG can be used as an effective inflammatory marker. ${ }^{[15,17,18,25-27]}$ Studies on the use of IG measurements in AA diagnosis and the discrimination between SA and CA are limited. ${ }^{[22,28,29]}$ Mathews et al. ${ }^{[28]}$ found that an increased IG\% was significant in the discrimination of acute and perforated appendicitis in the pediatric age group, but it did not bring any additional benefit to this discrimination when compared with an increased CRP level and shift to left. Shin et al. ${ }^{[22]}$ found that the delta neutrophil index (DNI), the IG fraction in circulation, was a reliable marker in discriminating between acute non-perforated appendicitis and acute perforated appendicitis among elderly individuals. Furthermore, they recommended carrying out immediate CT and emergency surgical intervention in elderly patients with suspicious appendicitis and a DNI > I.4. In another study, Shin et al. ${ }^{[29]}$ measured the DNI for use in discrimination between $\mathrm{AA}$ and $\mathrm{CA}$ among adults and showed that a $\mathrm{DNI}>2$ could be a reliable parameter for $\mathrm{AA}$ and $\mathrm{DNI}>6$ could identify $\mathrm{CA}$.

In the present study, there was a statistically significant difference between the NA and AA groups in all of the hematological parameters (WBC, NLR, IGC, IG\%). However, it was determined that the IGC was quite specific in diagnosing AA (AUROC: 0.795 , sensitivity: $55.5 \%$, specificity: $96.1 \%$ ). Moreover, all of the parameters were statistically significant when the SA and CA groups were compared; however, the IG\% had a greater ability to predict CA than the other parameters (AUROC: 0.979, sensitivity: $94.4 \%$, specificity: $97.9 \%$ ).

This study had certain limitations. Since it was a retrospective study, the data obtained were limited. Therefore, the inflam- 
mation parameters, such as CRP, were not included in the study. As measurement of the IG parameter in the CBC did not exist prior to April 2017, this study included cases after this date. Thus, the number of patients was limited. Furthermore, the length of time from the emergence of symptoms until presentation at the hospital could not be assessed. It is possible that this period affects the values of inflammatory markers.

\section{Conclusion}

Early diagnosis and treatment of ACA is very important since it reduces postoperative morbidity rates and medical costs. IG is a new inflammatory marker that is easily detected through a routine CBC without any additional time or cost. Based on the results of this study, it can be said that in cases of suspicious acute appendicitis, the IGC is a more reliable marker in predicting AA than the other hematological parameters, while the IG\% is a more reliable marker in predicting ACA.

\section{Conflict of interest: None declared.}

\section{REFERENCES}

1. Debnath J, Kumar R, Mathur A, Sharma P, Kumar N, Shridar N, et al. On the role of ultrasonography and CT scan in the diagnosis of acute appendicitis. Indian J Surg 2015;77:221-6. [CrossRef]

2. Nshuti R, Kruger D, Luvhengo TE. Clinical presentation of acute appendicitis in adults at the Chris Hani Baragwanath Academic Hospital. Int J Emerg Med 2014;7:12. [CrossRef]

3. Franz MG, Norman J, Fabri PJ. Increased morbidity of appendicitis with advancing age. Am Surg 1995;61:40-4.

4. Yamini D, Vargas H, Bangard F, Klein S, Stamas MJ. Perforated appendicitis: is it truly a surgical urgency? Am Surg 1998;64:970-5.

5. Lee JF, Leow CK, Lau WY. Appendicitis in the elderly. ANZ J Surg 2000;70:593-6.

6. Lunca S, Bouras G, Romedea NS. Acute appendicitis in the elderly patient: diagnostic problems, prognostic factors and outcomes. Rom J Gastroenterol 2004;13:299-303.

7. Paragiotopoulou IG, Parashar D, Lin R, Antonowicz S, Wells AD, Bojura FM, et al. The diagnostic value of white cell count, C-reactive protein and bilirubin in acute appendicitis and its complications. Ann R Coll Surg Engl 2013;95:215-21. [CrossRef]

8. Farooqui W, Pommergaard HC, Burcharth J, Eriksen JR. The diagnostic value of a panel of serological markers in acute appendicitis. Scand J Surg 2015;104:72-8. [CrossRef]

9. Kahramanca S, Ozgehan G, Seker D, Gökce EI, Seker G, Tunç G, et al. Neutrophil-to-lymphocyte ratio as a predictor of acute appendicitis. Ulus Travma Acil Cerrahi Derg 2014;20:19-22. [CrossRef]

10. Bröker ME, van Lieshout EM, van der Elst M, Stassen LP, Schepers T. Discriminating between simple and perforated appendicitis. J Surg Res 2012;176:79-83. [CrossRef]

11. McGoran DR, Sims HM, Zia K, Uheba M, Shaikh IA. The value of biochemical markers in predicting a perforation in acute appendicitis. ANZ J Surg 2013;83:79-83. [CrossRef]
12. Sevinç MM, Kınacı E, Çakar E, Bayrak S, Özakay A, Aren A, et al. Diagnostic value of basic laboratory parameters for simple and perforated acute appendicitis: an analysis of 3392 cases. Ulus Travma Acil Cerrahi Derg 2016;22:155-62.

13. Jung SK, Rhee DY, Lee WJ, Woo SH, Seol SH, Kim DH, et al. Neutrophil-to-lymphocyte count ratio is associated with perforated appendicitis in elderly patients of emergency department. Aging Clin Exp Res 2017;29:529-36. [CrossRef]

14. Senthilnayagam B, Kumar T, Sukumaran J, M J, Rao KR. Automated measurement of immature granulocytes: performance characteristics and utility in routine clinical practice. Pathol Res Int 2012;2012:483670.

15. Park JH, Byeon HJ, Lee KH, Lee JW, Kronbichler A, Eisenhut M, et al. Delta neutrophil index (DNI) as a novel diagnostic and prognostic marker of infection: a systematic review and meta-analysis. Inflamm Res 2017;66:863-70. [CrossRef]

16. Ansari-Lari MA, Kickler TS, Borowitz MJ. Immature granulocyte measurement using the Sysmex XE-2100. Relationship to infection and sepsis. Am J Clin Pathol 2003;120:795-9. [CrossRef]

17. Nigro KG, O'Riordan M, Molloy EJ, Walsh MC, Sandhaus LM. Performance of an automated immature granulocyte count as a predictor of neonatal sepsis. Am J Clin Pathol 2005;123:618-24. [CrossRef]

18. Park BH, Kang YA, Park MS, Jung WJ, Lee SH, Lee SK, et al. Delta neutrophil index as an early marker of disease severity in critically ill patients with sepsis. BMC Infect Dis 2011;11:299. [CrossRef]

19. Ozan E, Ataç GK, Alişar K, Alhan A. Role of inflammatory markers in decreasing negative appendectomy rate: A study based on computed tomography findings. Ulus Travma Acil Cerrahi Derg 2017;23:477-82.

20. Joshi MK, Joshi R, Alam SE, Agarwal S, Kumar S. Negative Appendectomy: an Audit of Resident-Performed Surgery. How Can Its Incidence Be Minimized? Indian J Surg 2015;77:913-7. [CrossRef]

21. Kartal K, Yazıcı P, Ünlü TM, Uludağ M, Mihmanlı M. How to avoid negative appendectomies: Can US achieve this? Ulus Travma Acil Cerrahi Derg 2017;23:134-8.

22. Shin DH, Cho YS, Kim YS, Ahn HC, Oh YT, Park SO, ET AL. Delta neutrophil index: A reliable marker to differentiate perforated appendicitis from non-perforated appendicitis in the elderly. J Clin Lab Anal 2018;32. [CrossRef]

23. Turhan AN, Kapan S, Kütükçü E, Yiğitbaş H, Hatipoğlu S, Aygün E. Comparison of operative and non operative management of acute appendicitis. Ulus Travma Acil Cerrahi Derg 2009;15:459-62.

24. Moon HM, Park BS, Moon DJ. Diagnostic value of C-reactive protein in complicated appendicitis. J Korean Soc Coloproctol 2011;27:122-6.

25. Lee H, Kim IK, Ju MK. Which patients with intestinal obstruction need surgery? The delta neutrophil index as an early predictive marker. Ann Surg Treat Res 2017;93:272-6. [CrossRef]

26. Lipiński M, Rydzewska G. Immature granulocytes predict severe acute pancreatitis independently of systemic inflammatory response syndrome. Prz Gastroenterol 2017;12:140-4. [CrossRef]

27. Lee JW, Kim SH, Park SJ, Lee KH, Park JH, Kronbichler A, et al. The value of delta neutrophil index in young infants with febrile urinary tract infection. Sci Rep 2017;7:41265. [CrossRef]

28. Mathews EK, Griffin RL, Mortellaro V, Beierle EA, Harmon CM, Chen $\mathrm{MK}$, et al. Utility of immature granulocyte percentage in pediatric appendicitis. J Surg Res 2014;190:230-4. [CrossRef]

29. Shin DH, Cho YS, Cho GC, Ahn HC, Park SM, Lim SW, et al. Delta neutrophil index as an early predictor of acute appendicitis and acute complicated appendicitis in adults. World J Emerg Surg 2017;12:32. 
ORİJINAL ÇALIŞMA - ÖZET

\section{Akut komplike apandisit tanısında yeni ve erken bir belirteç: İmmatür granülosit}

\section{Dr. Yılmaz Ünal}

Ankara Eğitim ve Araştırma Hastanesi, Genel Cerrahi Kliniği, Ankara

AMAÇ: Çalışmamızın amacı immatür granülosit sayısı (IGS) ve yüzdesinin (IG\%) hem akut apandisit tanısında hem de basit apandisit (BA) ile komplike apandisiti (KA) ayırmadaki etkinliğini araştırmaktır.

GEREÇ VE YÖNTEM: Bu çalışma apendektomi yapılan 438 erişkin hasta üzerinde yapıldı. Hastaların demografik verileri, beyaz küre (BK) sayımı, nötrofil/lenfosit oranı (NLO), IGS ve IG\%'si, ameliyat bulguları ve patoloji sonuçları geriye dönük olarak değerlendirildi. Hastalar patoloji raporlarına göre akut apandisit (AA) ve normal apendiks (NA) olarak, akut apandisitler de ameliyattaki bulgulara göre BA ve KA olarak gruplara ayrıldı.

BULGULAR: Beyaz küre, NLO, IGS, IG\% akut apandisit tanısında anlamlı parametrelerdi. Bu parametrelerin arasında IGS'nin AUROC, duyarlılık ve özgüllük değerleri diğerlerinden daha yüksek idi. IGC için AUROC; 0.795, duyarlılık: \%55.5, özgüllük: \%96. I idi. Tüm parametreler komplike apandisit tanısında da anlamlı idi ancak IG\%'nin komplike apandisit tanısındaki değeri diğer parametrelerden daha güçlü idi (AUROC: 0.979, duyarlılık: \%94.4, özgüllük: \%97.9 idi.

TARTIŞMA: Immatür granülosit hem akut apandisit tanısı koymada, hem de basit ve komplike apandisiti ayırmada hızlı, kolay ulaşılabilir ve güvenilir bir parametredir.

Anahtar sözcükler: Apandisit; immatüre granülosit; tanı.

Ulus Travma Acil Cerrahi Derg 2018;24(5):434-439 doi: 10.5505/tjtes.2018.9166। 